\title{
Diagnosis of lymphoma in paraffin wax sections by nested PCR and immunohistochemistry
}

\author{
Y Kitamura, E Nanba, S Inui, T Tanigawa, K Ichihara
}

\begin{abstract}
Aims-To investigate whether nested polymerase chain reaction (PCR) and immunohistochemistry can be used to diagnose malignant lymphoma.

Methods-Paraffin wax embedded tissue sections from 31 patients with malignant lymphoma were analysed by nested PCR and immunohistochemistry using standard protocols.

Results-Nested PCR amplification of 1 pg DNA confirmed monoclonality in $B$ cell lymphoma; PCR amplification of 10 pg DNA confirmed monoclonality in $T$ cell lymphoma. Twenty seven $(87 \%)$ samples were diagnosed as malignant lymphoma by nested PCR, and 24 (77\%) by immunohistochemistry. Seven samples were diagnosed as malignant lymphoma by nested PCR, but not by immunohistochemistry, whereas the use of both procedures gave a diagnosis of malignant lymphoma in all 31 samples.

Conclusions-A combination of immunohistochemistry and nested PCR can be used to diagnose malignant lymphoma in routine paraffin wax embedded sections. (f Clin Pathol 1996;49:333-337)
\end{abstract}

Keywords: malignant lymphoma, paraffin wax section, nested PCR, immunohistochemistry.

Second Department of Pathology, Tottori University Faculty of Medicine, Nishimachi 86, Yonago 683, Japan Y Kitamura

K Ichihara

Division of Child Neurology, Institute of Neurological Science E Nanba

Department of Immunology

$S$ Inui

Department of Bacteriology

T Tanigawa

Correspondence to: Dr Y Kitamura,

Second Department of

Second Department of Faculty of Medicine, Faculty of Medicine,
Nishimachi 86, Yonago 683, Japan.

Accepted for publication 21 November 1995

The diagnosis of malignant lymphoma cur rently depends on histological examination of paraffin wax embedded tissue samples. However, it is difficult to distinguish malignant from benign disorders in lymph nodes and other lymphoid tissues. Also, the differential diagnosis between lymphomas of $B$ and $T$ cell origin is important clinically as the prognosis of patients with $\mathrm{T}$ cell lymphoma is poorer than that of those with $\mathbf{B}$ cell lymphoma. ${ }^{1}$

Gene rearrangement is important diagnostic marker of malignant lymphoma. ${ }^{2}$ Rearrangements of the immunoglobulin and $\mathrm{T}$ cell receptor (TCR) genes are valuable markers for $\mathrm{B}^{3}$ and $\mathrm{T}$ cell lymphoma, ${ }^{4}$ respectively. Therefore, investigation of gene rearrangement may facilitate the routine diagnosis of malignant lymphoma, particularly when used in combination with immunohistochemistry.

The most common means of investigating gene rearrangements is Southern blotting, which requires large quantities of fresh tissue, special equipment and is time consuming. Whereas a large amount of fresh tissue is sometimes difficult to obtain, paraffin wax embedded material is readily available.
Given these considerations, polymerase chain reaction (PCR) is particularly useful for investigating gene rearrangements in a clinical setting. ${ }^{56}$ We used nested PCR in this study as it permits short term, sensitive analysis of small amounts of tissue. ${ }^{7}$

\section{Methods}

Thirty one paraffin wax embedded samples of non-Hodgkin's lymphoma from 15 men and 16 women (age range 29-86 years) were studied. Nineteen specimens were biopsy samples, five were obtained at surgery and seven at necropsy. The B cell lines, Nalm 6 and CESS, were used as $\mathrm{B}$ cell positive controls. ${ }^{8}$ The $\mathrm{T}$ cell lines, CCRF-CEM and Molt-4, were used as T cell positive controls. ${ }^{910}$ Negative controls consisted of lymphocytes from the peripheral blood of healthy volunteers and paraffin wax sections of normal lymph nodes.

All samples were examined initially by staining with haematoxylin and eosin. Serial sections were immunostained with a panel of antibodies including MB1 (CD45R), L26 (CD20), MT1 (CD43), UCHL1 (CD45RO), and polyclonal antibodies directed against $\kappa$ and $\lambda$ immunoglobulin light chains.

DNA was extracted from paraffin wax sections, $10 \mu \mathrm{m}$ thick, and purified as described previously. ${ }^{7}$ As the amount of purified DNA from paraffin wax embedded tissue was too low to detect by light absorption at an optical density of $260 \mathrm{~nm}$, the $\beta$ globin gene was amplified as a control for PCR.

\section{NESTED PCR}

Primer design

Oligonucleotide primers for the immunoglobulin heavy chain $(\operatorname{IgH})$ and TCR $\gamma$ chain genes were constructed on a DNA synthesiser (Applied Biosystems Model 392 Synthesiser, Foster, California, USA). The outer and inner pairs of primers were designed to amplify the CDRIII and CDRII regions of IgH. Primers for TCR $\gamma$ were designed in the same manner. The sequences for IgH, ${ }^{811-14} \mathrm{TCR} \gamma,{ }^{15-17}$ and these primers ${ }^{18-23}$ were as published. Primers used for IgH PCR were: F3v (outer): 5'GAC(A/T)C(A/G)GC(G/C)(G/A)TGTA(T/ C)T(T/A)CTG-3'; F3v (inner): 5'-ACACGGC(C/T)(G/C)TGTATTACTGT-3'; F2v (outer): $5^{\prime}$-TGG(A/G)TCCG(A/C)CAG(G/C) $\mathrm{C}(\mathrm{T} / \mathrm{C})(\mathrm{T} / \mathrm{C}) \mathrm{C}-3^{\prime} ; \mathrm{F} 2 \mathrm{v}$ (inner): 5'-GTCCTGCAGGC(C/T)(C/T)CCGG(A/G)AA(A/G) (A/G)GTCTGGAG-3'; BJ (outer): 5'-CTTACCTGAGGAGACGGTGA-3'; and BJ (inner): 5'-GTGACCAGGGT(T/C/G/A)CC- 


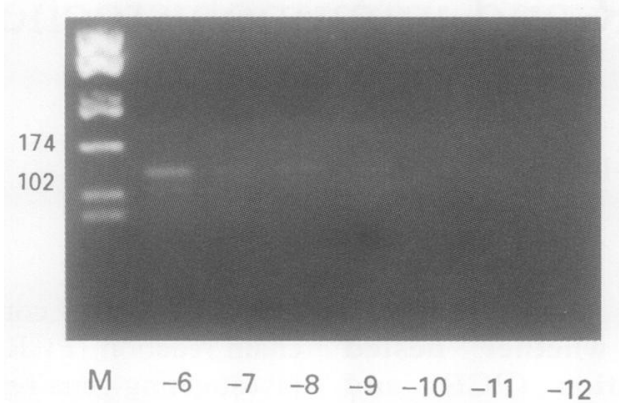

$\log (\mathrm{DNA})$

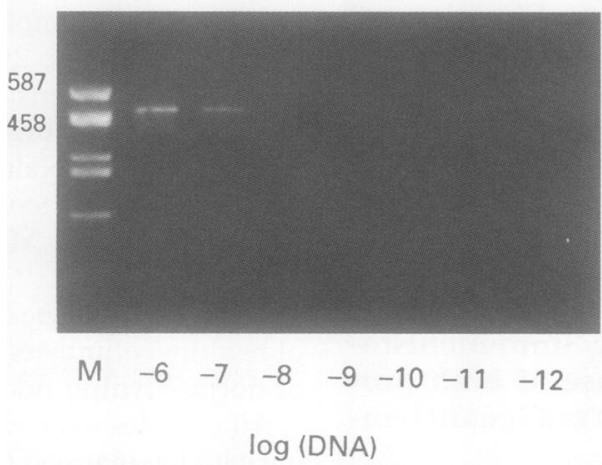

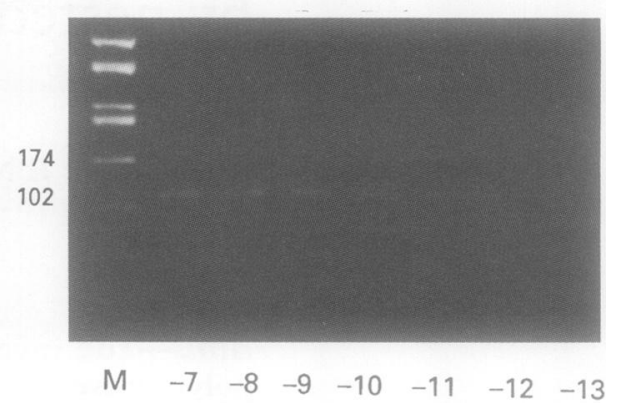

$\log (D N A)$

$\mathrm{TCR} \gamma$

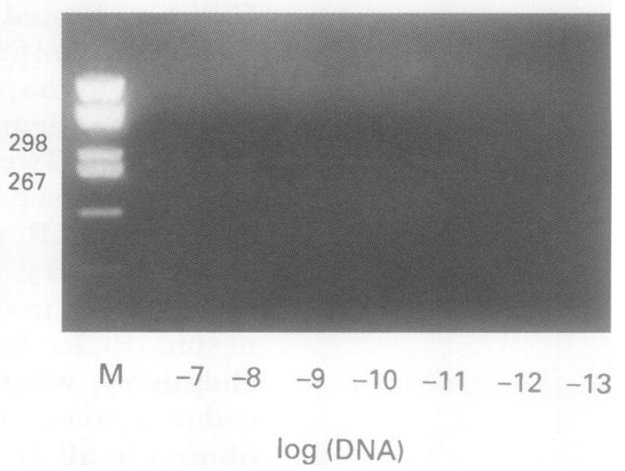

Figure 1 A comparison of sensitivity between PCR and nested PCR. IgH gene rearrangements were detected in 1 ng $D N A$ by PCR, but in 1 pg DNA by nested PCR. Similarly, TCR gene rearrangements were detected in 100 ng DNA by PCR, but in 10 pg DNA by nested PCR.

TTGGCCCCAG-3'. Primers used for TCR $\gamma$ PCR were: Tv (outer): 5'-GCTTCTAGCTTTCCTGTCTC-3'; Tv (inner): 5'-ACTACTACTGAAGCTTCTACATCCACTGGTACCT-3'; Tj (outer): 5'-GGATCCAACAAGTGTTGTTCCAC-3'; and Tj (inner): 5'CGTCGACAACAAGTGTTGTTCCAC-3'.

\section{PCR conditions}

PCR was essentially performed as described by Saiki et $a l .{ }^{56}$ The reaction mixture $(25 \mu \mathrm{l})$ contained $50 \mathrm{pmol}$ of each primer, $1 \mathrm{mM}$ of dNTPs, $1 \times$ Taq buffer, $10 \%$ dimethyl sulphoxide, Taq polymerase, and a DNA template. Each reaction mixture was covered with $50 \mu 1$ light mineral oil. One PCR cycle consisted of denaturation for one minute at $94^{\circ} \mathrm{C}$, annealing for two minutes at $60^{\circ} \mathrm{C}$ and extension for two minutes at $72^{\circ} \mathrm{C}$. The first stage of PCR amplification consisted of 30 cycles with the outer pair of primers and the second stage of 30 cycles with the inner pair of primers and $1 / 1000$ of the PCR product generated in the first stage.

The PCR products were visualised by means of electrophoresis on 3\% agarose gels stained with ethidium bromide. Puc19/HaeIII was used as a size marker.
Subcloning and non-radioisotopic sequencing of the PCR products

The PCR products were subcloned into the pGEM T-vector. Briefly, PCR products were extracted from a low melting point agarose gel, ligated to the pGEM T-vector, and transformed into competent cells, which were then incubated in LB agar plates containing $\mathrm{X}-\mathrm{Gal}$ and IPTG (isopropyl-1-thio- $\beta$-D-galactoside). White colonies were selected and cultured at $37^{\circ} \mathrm{C}$ for 16 hours, after which the plasmid was extracted.

The PCR products were sequenced by means of dideoxy-mediated chain-termination using a biotin labelled $\mathrm{T} 7$ promoter primer for the cycle sequence. After urea denaturing polyacrylamide gel electrophoresis, biotin was detected with Streptavidin alkaline phosphatase and lumistain.

\section{Results}

SENSITIVITY OF THE NESTED PCR SYSTEM

The PCR products from Nalm 6 and CESS using the outer and inner pairs of primers for the CDRIII locus of the IgH gene were 90-130 base pairs (bp), whereas those for CDRII were $220-60 \mathrm{bp}$. The product generated by the outer pair of primers was longer than that generated 

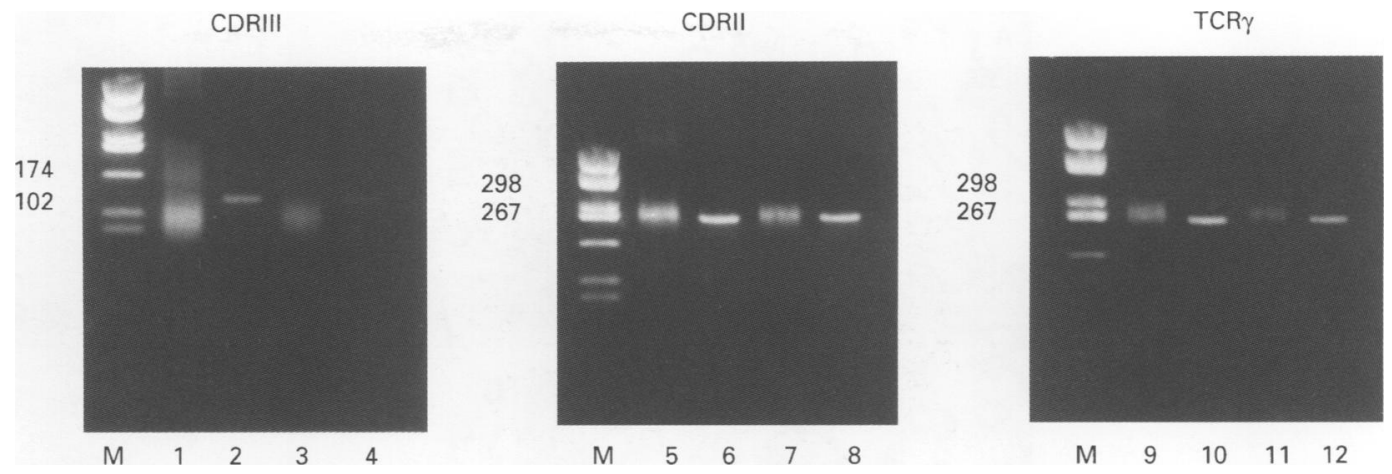

Figure 2 Gene rearrangements in cell lines and paraffin wax sections. Lanes 1, 5 and 9, lymphocytes from healthy peripheral blood; lanes 3, 7 and 11, paraffin wax sections of a normal lymph node; lanes 2 and 6, Nalm 6; lane 10, CCRF-CEM; lanes 4 and 8, paraffin wax section of $B$ cell lymphoma; and lane 12, paraffin wax section of $T$ cell lymphoma.

by the inner pair. The PCR products of the TCR $\gamma$ gene from CCRF-CEM and Molt-4 were about $230-70$ bp (data not shown).

IgH gene rearrangement could be detected in 1 pg DNA by nested PCR, compared with at least $1 \mathrm{ng}$ required for the detection of gene rearrangement when only the outer pair of primers was used. Similarly, TCR $\gamma$ gene rearrangement could be detected in $10 \mathrm{pg}$ DNA by nested PCR, whereas PCR using only outer pair of primers required $100 \mathrm{ng}$ of DNA (fig 1).

\section{COMPARISON BETWEEN}

IMMUNOHISTOCHEMISTRY AND NESTED PCR

Figure 2 shows the results of detection of $B$ cell and $\mathrm{T}$ cell lymphomas extracted from paraffin wax sections using nested PCR. A faint smear can be seen for the negative control.

Table 1 shows the clinical data, localisation of the malignant lymphomas, and the results of immunohistochemical analysis and nested PCR of the 31 samples. Immunohistochemistry confirmed B cell origin in 21 samples, in which most lymphoma cells were immunoreactive for
L26 (fig 3A), MB1, and Igא or Ig $\lambda$. Three specimens were classified as $\mathrm{T}$ cell lymphoma because they were immunoreactive for UCHL1 (fig 3B) or MT1. Seven samples were immunoreactive for both $B$ and $T$ cell markers.

Of the $21 \mathrm{~B}$ cell lymphomas, nested PCR demonstrated IgH gene rearrangement in 18 $(85.7 \%)$, of which four were CDRIII positive, three were CDRII positive, and 11 were both CDRIII and CDRII positive. In addition to IgH gene rearrangement, a single TCR $\gamma$ gene band was detected in nine samples. There were no single bands for IgH and TCR $\gamma$ in three samples. Two of three $\mathrm{T}$ cell lymphomas had TCR $\gamma$ gene rearrangements, while sample 22 had no single bands. The seven samples, in which the cell origin could not be determined by immunohistochemistry, consisted of five B and two $\mathrm{T}$ cell lymphomas, the diagnosis of which was confirmed by the presence of a single band for IgH and TCR $\gamma$, respectively.

Thus, the cell origin of the lymphomas was confirmed in 24 samples $(77 \cdot 4 \%)$ by immunohistochemistry and in $27(87 \cdot 1 \%)$ by nested

Table 1 Results of immunohistochemistry and PCR analysis of 31 malignant lymphomas

\begin{tabular}{|c|c|c|c|c|c|c|c|}
\hline \multirow[b]{2}{*}{ Case number } & \multirow[b]{2}{*}{ Age (years) } & \multirow[b]{2}{*}{ Sex } & \multirow[b]{2}{*}{ Organ } & \multirow[b]{2}{*}{ Immunohistochemistry } & \multicolumn{3}{|c|}{ Gene rearrangements } \\
\hline & & & & & $C D R I I I$ & $C D R I I$ & $T C R_{i}$ \\
\hline 1 & 54 & $\mathrm{~F}$ & Skin & B & + & + & + \\
\hline 2 & 68 & $\mathrm{~F}$ & Stomach & B & + & + & + \\
\hline 3 & 72 & M & Colon & B & - & - & - \\
\hline 4 & 86 & $\mathrm{~F}$ & Thyroid & B & - & - & - \\
\hline 5 & 77 & $\mathrm{~F}$ & Lymph node & $\mathbf{B}$ & - & - & - \\
\hline 6 & 62 & M & Stomach & B & + & + & + \\
\hline 7 & 74 & M & Stomach & B & + & - & + \\
\hline 8 & 76 & $\mathrm{~F}$ & Lymph node & $\mathbf{B}$ & + & - & - \\
\hline 9 & 70 & $\mathrm{~F}$ & Stomach & $\mathbf{B}$ & + & - & + \\
\hline 10 & 70 & $\mathrm{~F}$ & Lymph node & B & + & - & - \\
\hline 11 & 59 & $\mathrm{~F}$ & Stomach & B & - & + & - \\
\hline 12 & 72 & $\mathrm{~F}$ & Lymph node & $\mathbf{B}$ & - & + & - \\
\hline 13 & 79 & M & Lymph node & $\mathbf{B}$ & + & + & + \\
\hline 14 & 76 & $\mathrm{~F}$ & Stomach & B & + & + & - \\
\hline 15 & 56 & $\mathrm{~F}$ & Colon & B & + & + & - \\
\hline 16 & 59 & $\mathrm{~F}$ & Stomach & $\mathbf{B}$ & - & + & - \\
\hline 17 & 48 & $\mathbf{M}$ & Duodenum & B & + & + & + \\
\hline 18 & 64 & $\mathrm{~F}$ & Stomach & B & + & + & + \\
\hline 19 & 82 & $\mathbf{M}$ & Tonsil & B & + & + & - \\
\hline 20 & 29 & $\mathbf{M}$ & Penis & $\mathbf{B}$ & + & + & - \\
\hline 21 & 69 & M & Bone marrow & $\mathbf{B}$ & + & + & + \\
\hline 22 & 76 & $\mathbf{M}$ & Skin & $\mathrm{T}$ & - & - & - \\
\hline 23 & 64 & M & Lymph node & $\mathrm{T}$ & - & - & + \\
\hline 24 & 62 & $\mathbf{M}$ & Lymph node & $\mathrm{T}$ & - & - & + \\
\hline 25 & 80 & $\mathbf{M}$ & Lymph node & ND & + & + & - \\
\hline 26 & 67 & M & Lymph node & ND & - & - & + \\
\hline 27 & 57 & $\mathrm{~F}$ & Lymph node & ND & - & + & - \\
\hline 28 & 79 & $\mathbf{M}$ & Lymph node & ND & + & - & - \\
\hline 29 & 77 & $\mathrm{~F}$ & Tonsil & ND & + & - & - \\
\hline 30 & 81 & $\mathbf{F}$ & Lymph node & ND & + & + & - \\
\hline 31 & 83 & $\mathbf{F}$ & Lymph node & ND & - & - & + \\
\hline
\end{tabular}



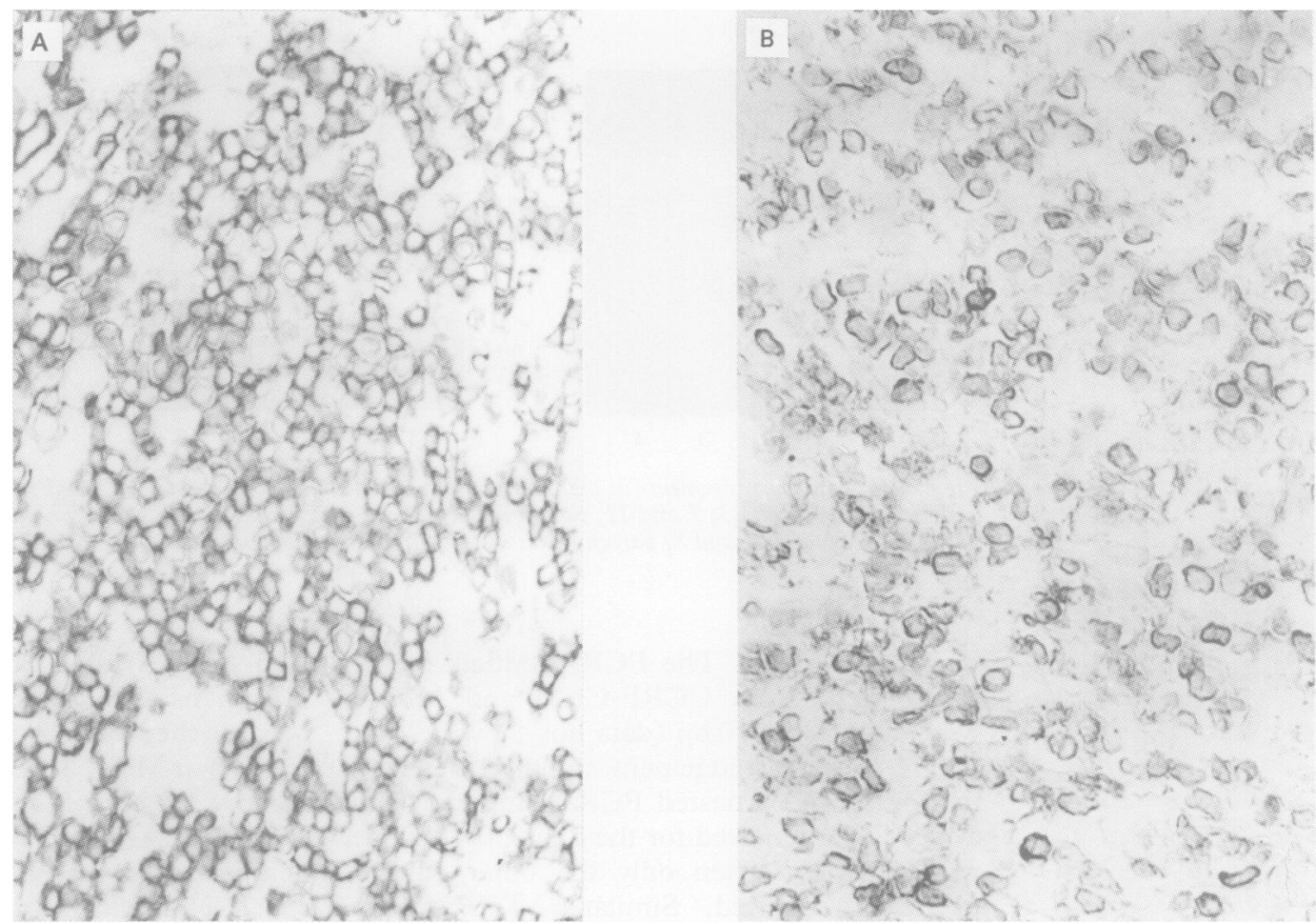

Figure 3 Immunohistochemical staining ( $\times 132)$ with $(A)$ L26 and (B) UCHL1 antibodies.

PCR. The use of both procedures allowed us to determine the cell origin in all 31 samples.

Sequencing revealed conserved regions of IgH and TCR $\gamma$ following the cloning site of the vector. This confirmed that the PCR products were in fact derived from IgH and TCR $\gamma$ gene rearrangements (data not shown).

\section{Discussion}

We detected IgH and TCR $\gamma$ gene rearrangements in paraffin wax specimens by nested PCR. Nested PCR does not require a definitive band in the first stage, so the annealing temperature can be set relatively high, thus increasing the specificity. Moreover, the procedure was sensitive enough to detect gene rearrangement in $1 \mathrm{pg}$ of DNA, equivalent to the amount of DNA in a single cell. In paraffin wax samples $87 \%$ of malignant lymphomas could be detected by nested PCR, whereas using only the outer pair of primers, only $39 \%$ of malignant lymphomas were detected.

We examined the sequences of the PCR products to confirm that PCR actually amplified the IgH and TCR $\gamma$ genes. The sequences of the conserved regions of the IgH and TCR $\gamma$ genes were found after that of the cloning vector.

Some investigators have examined IgH gene rearrangement using PCR, especially the CDRIII locus. ${ }^{2425}$ Because the rearrangement of the light chain is complex and is unsuitable for PCR, we examined IgH gene rearrangements. The detection rate of malignant lymphoma using the CDRIII locus is only about $80 \% .^{19}$ Therefore, examination of another IgH locus is required to identify false negative results. Ramasamy et al ${ }^{19}$ examined the CDRII locus and reported that there are some instances where samples are CDRIII negative, CDRII positive, suggesting that examination of the CDRII locus would facilitate the identification of false negative results. We therefore examined the CDRIII and CDRII loci. In three samples in the present study rearrangements were detected in the CDRII locus only.

TCR gene rearrangement occurs in the following sequence: $\delta, \gamma, \beta$, and $\alpha$. Moreover, because the $\delta$ chain locus is included within the $\alpha$ chain, $\delta$ chain deletions are observed when the $\alpha$ chain rearranges. Though rearrangements are occasionally observed in the $\delta$ chain only, almost all of them are found in the $\gamma$ chain. $\beta$ and $\gamma$ chain rearrangements can be identified by Southern blotting, but the rearranged profile of the $\beta$ chain is complex. Therefore, rearrangement of the $\gamma$ chain can be detected more readily by PCR than that of the $\beta$ chain. ${ }^{2627}$ In fact, we obtained satisfactory results by analysing the $\gamma$ chain.

Chen $e t a l^{28}$ reported that the TCR $\gamma$ gene is frequently rearranged in $\mathrm{B}$ cell malignancies. In the present study, both the IgH and TCR $\gamma$ genes were rearranged in nine samples, which were also B cell marker positive by immunohistochemistry.

Histological diagnosis is often difficult when the biopsy specimen is too small, when an artefact is prominent, or when necrosis is present. In seven of the 31 samples examined in this study, a definitive diagnosis of malignant lymphoma could not be made by histology alone. A diagnosis of malignant lymphoma was confirmed by examining gene rearrangement using nested PCR. However, gene rearrangements were not detected in four samples. These samples had been fixed in formaldehyde for a long period of time and the 
DNA had probably degraded. Immunohistochemistry confirmed the diagnosis in these samples.

In conclusion, $77 \%$ of 31 malignant lymphomas were diagnosed by immunohistochemistry and $87 \%$ by nested PCR. Moreover, all 31 samples were correctly diagnosed by a combination of nested PCR and immunohistochemistry. We conclude that both nested PCR and immunohistochemistry are essential for routine diagnostic studies of paraffin wax sections of malignant lymphoma.

We thank Dr C Glenn Begley from The Walter and Eliza Hall Institute of Medical Research for helpful advice and Dr M Motoi from the Tottori University Faculty of Medicine for providing the paraffin wax sections.

1 Krajewski AS, Myskow MW, Cachia PG, Salter DM, Sheehan $\mathrm{T}$, Dewar AE. T-cell lymphoma: morphology, immunophenotype and clinical features. Histopathology 1988 ; 13:19-41.

2 Griesser H, Tkachuk D, Reis MD, Mak TW. Gene rearrangements and translocations in lymphoproliferative diseases. Blood 1989;73:1402-15.

3 Cleary ML, Chao J, Warnke R, Sklar J. Immunoglobulin gene rearrangement as a diagnostic criterion of B-cell lymphoma. Proc Natl Acad Sci USA 1984;81:593-7.

4 Minden MD, Toyonaga B, Ha K, Yanagi Y, Chin B, Gelfand $\mathrm{E}$, et al. Somatic rearrangement of T-cell antigen receptor gene in human T-cell malignancies. Proc Natl Acad Sci USA $1985 ; 82: 1224-7$.

5 Saiki RK, Scharf S, Faloona F, Mullis KB, Horn GT, Erlich $\mathrm{HA}$, et al. Enzymatic amplification of $\beta$-globin genomic sequences and restriction site analysis for diagnosis of sickle cell anemia. Science 1985;230:1350-4.

6 Saiki RK, Gelfand DH, Stoffel S, Scharf SJ, Higuchi R, Horn GT, et al. Primer-directed enzymatic amplification of DNA with a thermostable DNA polymerase. Science 1988;239:487-91.

7 Wan JH, Trainor KJ, Brisco MJ, Morley AA. Monoclonality in B cell lymphoma detected in paraffin wax embedded sections using the polymerase chain reaction. 7 Clin Pathol 1990;43:888-90.

8 Brisco MJ, Tan LW, Orsborn AM, Morley AA. Development of a highly sensitive assay, based on the polymerase chain reaction, for rare B-lymphocyte clones in a polyclonal population. Br $\mathcal{F}$ Haematol 1990;75:163-7.

9 Foley GE, Lazarus H, Farber S, Uzman BG, Boone BA, McCarthy RE. Continuous culture of human lymphoblasts from peripheral blood of a child with acute leukemia. Cancer 1965;18:522-9.

10 Srivastava BIS, Minowada J. Terminal deoxynucleotidyl transferase activity in a cell line (MOLT-4) derived from the peripheral blood of a patient with acute lymphoblastic leukemia. Biochem Biophys Res Commun 1973;51:529-35.

11 Rechavi G, Bienz B, Ram D, Neriah YB, Cohen JB, Zakut $\mathrm{R}$, et al. Organization and evolution of immunoglobulin
$\mathrm{V}_{\mathrm{H}}$ gene subgroups. Proc Natl Acad Sci USA 1982;79: $\mathrm{V}_{\mathrm{H}}$ gene

12 Rechavi G, Ram D, Glazer L, Zakut R, Givol D. Evolutionary aspects of immunoglobulin heavy chain variable region $\left(\mathrm{V}_{\mathrm{H}}\right)$ gene subgroups. Proc Natl Acad Sci USA 1983; 80:855-9.
13 Takahashi N, Noma T, Honjo T. Rearranged immunoglobulin heavy chain variable region $\left(\mathrm{V}_{\mathrm{H}}\right)$ pseudogene that deletes the second complementarity-determining region. Proc Natl Acad Sci USA 1984;81:5194-8.

14 Cleary ML, Meeker TC, Levy S, Lee E, Trela M, Sklar J, et al. Clustering of extensive somatic mutations in the variable region of an immunoglobulin heavy chain gen
from a human B cell lymphoma. Cell 1986;44:97-106.

15 Lefranc MP, Rabbitts TH. Two tandemly organized human genes encoding the T-cell $\gamma$ constant-region sequences show multiple rearrangement in different $\mathrm{T}$-cell types. Nature 1985;316:464-6.

16 Lefranc MP, Forster A, Rabbitts TH. Rearrangement of two distinct $T$-cell $\gamma$-chain variable-region genes in human DNA. Nature 1986;319:420-2.

17 LeFranc MP, Forster A, Baer R, Stinson MA, Rabbitts $T H$. Diversity and rearrangement of the human $T$ cell rearranging $\gamma$ genes: Nine germ-line variable genes berearranging $\gamma$ genes: Nine germ-line variable gent
longing to two subgroups. Cell 1986;45:237-46.

18 Kiyoi H, Naoe T, Horibe K, Ohno R. Characterization of the immunoglobulin heavy chain complementarity determining region (CDR)-III sequences from human B cell precursor acute lymphoblastic leukemia cells. $\mathcal{F}$ Clin Invest 1992;89:739-46.

19 Ramasamy I, Brisco M, Morley A. Improved PCR method for detecting monoclonal immunoglobulin heavy chain rearrangement in B cell neoplasms. F Clin Pathol 1992; 45:770-5.

20 Bourguin A, Tung R, Galili N, Sklar J. Rapid, nonradioactive detection of clonal T-cell receptor gene rearrangements detection of clonal T-cell receptor gene rearrangements
in lymphoid neoplasms. Proc Natl Acad Sci USA 1990;87: in lymphoid

21 Volkenandt M, Soyer HP, Kerl H, Bertino JR. Development of a highly specific and sensitive molecular probe for detection of cutaneous lymphoma. F Invest Dermatol 1991; 97:137-40.

22 Lorenzen J, Jux G, Höhn MZ, Klöckner A, Fischer R, Hansmann ML. Detection of T-cell clonality in paraffinembedded tissues. Diagn Mol Pathol 1994;3:93-9.

23 Ilyas $M$, Jalal $\mathrm{H}$, Linton C, Rooney N. The use of the polymerase chain reaction in the diagnosis of B-cell lympolymerase chain reaction in the diagnosis of B-cell lymphomas from formalin-fixed
Histopathology 1995;26:333-8.

24 Yamada M, Hudson S, Tournay O, Bittenbender S, Shane SS, Lange B, et al. Detection of minimal disease in hematopoietic malignancies of the B-cell lineage by using thirdcomplementarity-determining region (CDR-III)-specific probes. Proc Natl Acad Sci USA 1989;86:5123-7.

25 Liang R, Chan V, Chan TK, Wong T, Chiu E, Todd D. Detection of immunoglobulin gene rearrangement in acute and chronic lymphoid leukemias of B-cell lineage by polymerase chain reaction gene amplification. Am $\mathcal{f}$ Hematol 1991;38:189-93.

26 Tycko B, Palmer JD, Link MP, Smith SD, Sklar J. Polymerase chain reaction amplification of rearranged antigen receptor genes using junction-specific oligonucleotides: possible application for detection of minimal residual disease in acute lymphoblastic leukemia. Cancer Cells 1989; 7:47-52.

27 Macintyre EA, d'Auriol L, Duparc N, Leverger G, Galibert $\mathrm{F}$, Sigaux F. Use of oligonucleotide probes directed against $T$ cell antigen receptor gamma delta variable-(diversity)joining junctional sequences as a general method for detecting minimal residual disease in acute lymphoblastic leukemias. 7 Clin Invest 1990;86:2125-35.

28 Chen Z, Paslier DL, Dausset J, Degos L, Flandrin G, Cohen $\mathrm{D}$, et al. Human $\mathrm{T}$ cell $\gamma$ genes are frequently rearranged in B-lineage acute lymphoblastic leukemias but not in chronic B cell proliferations. F Exp Med 1987;165:1000-15. 